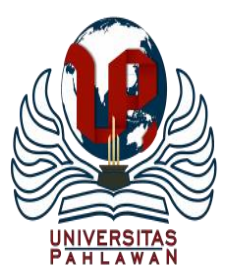

Edukatif : Jurnal Ilmu Pendidikan Volume 3 Nomor 2 Tahun 2021 Halm 396 - 403 EDUKATIF: JURNAL ILMU PENDIDIKAN

Research \& Learning in Education

https://edukatif.org/index.php/edukatif/index

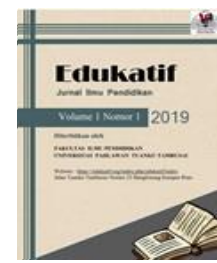

\title{
Penerapan Hasil Belajar Mata Pelajaran Ekonomi dengan Model Pembelajaran Coorperative Script
}

\author{
Marsel Nande ${ }^{1 凶}$, Yosef Moan Banda ${ }^{2}$, Yoventa Mbaru ${ }^{3}$ \\ Universitas Flores $1,2,3$ \\ E-mail : $\underline{\text { marselnande@gmail.com }}{ }^{1}$, yosmoan@gmail.com ${ }^{2}, \underline{\text { mbaru78@gmail.com }^{3}}$
}

\begin{abstract}
Abstrak
Mata pelajaran Ekonomi sangat penting bagi para siswa SMA, namun kenyataannya banyak siswa yang tidak termotivasi untuk belajar yang berakibat pada rendahnya hasil belajar siswa. Salah satu penyebabnya adalah model pembelajaran yang diterapkan dalam pembelajaran. Penelitian ini bartujuan untuk meningkatkan hasil belajar mata pelajaran ekonomi dengan menerapkan pembelajaran cooperative script. Jenis Penelitian adalah PTK dengan menerapkan model pembelajaran coopertive script terhadap hasil belajar peserta didik pada mata pelajaran ekonomi materi ajar perilaku konsumen dan produsen kelas X di SMAK Tarvid Ende. Hasil penelitian ini menunjukan hasil belajar peserta didik pada mata pelajaran ekonomi materi ajar perilaku konsumen dan produsen dengan menggunakan model pembelajaran cooperative script dapat ditingkatkan dimana pada siklus I nilai rata-rata di kelas adalah 77,14 dengan presentase ketuntasan $80,95 \%$ dan nilai ratarata kelas pada siklus II adalah 79,04 dengan presentase ketuntasan $100 \%$. Hasil penelitian ini memberikan contoh praktik baik penerapan model pembelajaran cooperative Script pembelajaran mata pelajaran ekonomi di SMA sehingga dapat dijadikan contoh bagi guru dan sekolah lain jika mengalami masalah yang serupa.
\end{abstract}

Kata Kunci : Pembelajaran Cooperative Script dan Hasil Belajar.

\begin{abstract}
Economics subject is very important for high school students, but in fact many students are not motivated to learn which results in low student learning outcomes. One of the reasons is the learning model applied in the learning process. This study aims to improve learning outcomes in economic subjects by applying cooperative script learning. This research is a Classroom Action Research (CAR) by applying a coopertive script learning model to the learning outcomes of students in economic subjects in the material Consumer and Producer's Behavior class $X$ at Tarvid Ende Senior High School. The results of this study indicate that the learning outcomes of students in the economics subject in material Consumer and Producer's Behavior by using the cooperative script learning model can be improved. In cycle I, the average grades in the class was 77.14 with a percentage of completeness $80.95 \%$. The average of students' grade in cycle II was 79.04 with a percentage of completeness $100 \%$. The results of this study provide examples of good implementation in the application of the cooperative learning script learning model for economic subjects in high school so that it can be used as an example for teachers and other schools if they experience similar problems.
\end{abstract}

Keywords: Cooperative Script, learning outcome.

Copyright (c) 2021 Marsel Nande, Yosef Moan Banda, Yofenta Mbaru

$\square$ Corresponding author

Email : marselnande@gmail.com

DOI $\quad:$ https://doi.org/10.31004/edukatif.v3i2.319

ISSN 2656-8063 (Media Cetak)

ISSN 2656-8071 (Media Online)

Edukatif : Jurnal Ilmu Pendidikan Vol 3 No 2 Tahun 2021 p-ISSN 2656-8063 e-ISSN 2656-8071 
397 Penerapan Hasil Belajar Mata Pelajaran Ekonomi dengan Model Pembelajaran Coorperative Script Marsel Nande, Yosef Moan Banda, Yofenta Mbaru

DOI: https://doi.org/10.31004/edukatif.v3i2.319

\section{PENDAHULUAN}

Pendidikan merupakan salah satu usaha meningkatkan kualitas hidup manusia melalui pengembangan potensi yang dimiliki (Ningrum, 2016). Pendidikan bukanlah kegiatan yang sederhana, melainkan kegiatan yang dinamis (Fakhruddin, 2011; Kusmayadi, 2017). Mempertimbangkan adanya dinamika penyelenggaraan pendidikan, maka pendidikan memerlukan manajemen yang baik agar tujuan pendidikan tercapai dengan efektif dan efisien (Ekawati, 2018; Supiana et al., 2018) termasuk manajemen dalam pembelajaran di kelas khususnya pemilihan strategi dan atau pendekatan pembelajaran yang tepat.

Pemilihan strategi, pendekatan, dan model pembelajaran yang tepat akan sangat sangat menentukan hasil belajar yang akan dicapai oleh siswa (Alie, 2013; Darkasyi et al., 2014) termasuk dalam mata pelajaran Ekonomi di kelas X SMA. Interaksi sebagai bagian dari proses belajar siswa dan guru dalam pembelajaran akan terjadi jika pembelajaran berjalan menarik dan tidak membosankan. Mata pelajaran ekonomi sangat penting diberikan kepada siswa di tingkat SMA karena berhubungan langsung dengan proses mengarungi hidup dan kehidupan ketika siswa telah lulus SMA. Mata pelajaran ekonomi merupakan bidang keilmuan yang mempelajari tentang kebutuhan hidup setiap manusia, perilaku konsumen dan produsen. Dari uraian tujuan pembelajaran tersebut, dapat dijelaskan betapa pentingnya pelajaran Ekonomi diterapkan kepada peserta didik.

Pada kenyataannya, guru mata pelajaran ekonomi mengeluhkan minat dan motivasi siswa yang rendah ketika mengikuti pelajaran. Banyak siswa yang beranggapan bahwa mata pelajaran ekonomi mudah bagi mereka. Anggapan ini tidak jadi masalah jika dibarengi dengan penguasaan yang baik materi-materi yang diajarkan. Namun berdasarkan hasil wawancara dengan guru mata pelajaran, banyak siswa yang tidak tuntas dalam belajar mata pelajaran ini. Untuk itu, peneliti berupaya menggali akar permasalahannya. Berdasarkan hasil wawancara dengan ibu ES, guru Ekonomi SMATaruna Vidya Ende, adapun pembelajaran sudah dilakukan adalah dengan menggunakan metode ceramah diselingi dengan tanya jawab dan pemberian tugas.

Berdasarkan hasil wawancara ini, kuat dugaan bahwa penerapan pendekatan atau metode pembelajaran yang tidak bervariasi menyebabkan siswa bosan dan tidak berminat dan memiliki motivasi yang rendah. Kenyataan ini tentu sangat merugikan mengingat minat belajar sangat perpengaruh terhadap hasil belajar. Minat belajar yang tinggi akan berdampak kepada hasil belajar yang baik juga, demikian pun sebaliknya (Rosdi, 2020; Sutardi \& Sugiharsono, 2016). Selanjutnya berdasarkan observasi langsung di kelas, tampak bahwa sebagian siswa saja yang antusias dan bersemangat dalam berdiskusi. Sedangkan sebagian besar siswa yang lainnya terlihat berceritadan hanya menyalin jawaban temannya yang lain dan pada kegiatan ini juga kurang terlihat interaksi antar siswa dan guru.

Situasi pembelajaran seperti ini perlu diperbaiki, salah satunya dengan menerapkan model pembelajaran yang sesuai. Salah satu model pembelajaran yang cocok diterapkan adalah model pembelajaran kooperatif. Secara umum model pembelajaran yang bersifat kooperatif dianggap lebih terstruktur, lebih preskriptif kepada guru tentang teknik kelas, lebih direktif kepada siswa tentang bagaimana bekerja dalam satu kelompok (Meilani \& Sutarni, 2016). Model pembelajaran kooperatif terdiri dari berbagai tipe, salah satunya yaitu model pembelajaran cooperative script. Model pembelajaran ini dapat diterapkan pada pembelajaran yang bersifat kognitif, karena setiap peserta didik nantinya diberikan materi ajar secara lengkap, dibagi berpasang pasangan dan masing-masing dari mereka bergantian secara lisan mengintisarikan materi yang telah diberikan, dan pasangan lainnya mengoreksi apakah benar pernyataan yang diungkapkan oleh temannya tersebut atau tidak (Lambiotte et al., 1988; Meilani \& Sutarni, 2016; Rahayaan et al., 2016). Selain itu model pembelajaran coooperative script dapat membuat peserta didik berpikir secara sistematis dan dapat fokus terhadap materi yang sedang dipelajari. 
398 Penerapan Hasil Belajar Mata Pelajaran Ekonomi dengan Model Pembelajaran Coorperative Script Marsel Nande, Yosef Moan Banda, Yofenta Mbaru

DOI: https://doi.org/10.31004/edukatif.v3i2.319

Beberapa penelitian yang menggunakan pembelajaran cooperative script antara lain yang dilakukan oleh Darojat et al., (2018), Jailani \& Qudsiyah (2020) serta Lumbanbatu (2020) menunjukkan bahwa model pembelajaran tersebut efektif meningkatkan hasil belajar siswa baik dalam sisi kognisi, afeksi maupun psikomotorik. Oleh karena itu, masalah pembelajaran yang ditemukan pada SMA Taruna Vidya Ende, NTT penting untuk diatasi dengan menggunakan pembelajaran cooperatif script. Masalah pembelajaran perlu diselesaikan mengingat harapan akan prestasi belajar yang tinggi dalam mata pelajaran ekonomi yang sangat penting bagi siswa dimana kenyataan ditemukan banyak siswa yang tidak menguasai konsep-konsep ekonomi seperti tuntutan kurikulum.

\section{METODE PENELITIAN}

Penelitian ini terfokus pada penerapan model pembelajaran cooperative script dalam hasil belajar peserta didik. Sehubungan ini maka jenis penelitian yang digunakan dalam penelitian ini adalah penelitian tindakan kelas (PTK). Desain penelitian tindakan model kemmis dan McTaggart lebih berfokus pada aspek individual dalam penelitian tindakan. Model ini dapat dikembangkan menjadi model PTK. Alur pikir dan alur kerja yang ditawarkan oleh kemmis dan McTaggart yaitu perencanaan, tindakan dan opservasi dan refleksi. Lokasi penelitian dilakukan di SMAK Tarvid Ende kecamatan Ende Tengah, Kabupaten Ende. Penelitian dilaksanakan selama pada bulan Januari 2019.Subyek penelitian pada penelitian tindakan kelas (PTK) adalah Guru mata pelajaran ekonomi, dan siswa sebanyak 21 orang dengan rincian laki-laki 17 orang, dan perempuan sebanyak 4 orang.

Metode ini digunakan untuk memperoleh data tentang hasil belajar peserta didik dengan materi perilaku konsumen dan produsen Kelas X pada SMAK Taruna Vidya Ende. Jenis tes yang digunakan dalam penelitian ini yaitu tes tertulis pre-tes (tes awal), (LKS) dan evaluasi yang dikerjakan secara individu. Data hasil observasi tentang aktivitas guru dalam menerapkan cara belajar dianalisis dengan menggunakan rumus presentase (total skor dibagi skor ideal di kali 100\% ). Untuk menganalisis tingkat keberhasilan atau presentase keberhasilan peserta didik setelah proses belajar mengajar setiap siklus dilakukan dengan cara memberikan evaluasi berupa soal tes tertulis pada setiap akhir siklus. Analisis ini dihitung dihitung dengan menggunakan statistik sederhana yaitu nilai rata-rata dan persentase dan menghitung ketuntasan belajar.

Berdasarkan petunjuk pelaksanaan belajar mengajar yaitu seorang peserta didik telah tuntas belajar bila telah mencapai skor 6,5 atau 65, dan kelas disebut tuntas belajar bila di kelas tersebut terdapat $85 \%$ yang telah mencapai ketuntasan lebih dari atau sama dengan $65 \%$.

\section{HASIL DAN PEMBAHASAN PENELITIAN}

Penelitian tindakan kelas ini dilaksanakan di kelas X SMA Tarvid Ende Tahu pelajaran 2018/2019 pada semester dua dengan jumlah peserta didik 21 orang yang terdiri dari 17 orang laki-laki dan 4 orang perempuan. Siklus 1 terdiri dari satu kali pertemuan dengan materi perilaku konsumen dan produsen (1) mendeskripsikan pengertian perilaku konsumen dan produsen (2) menjelaskan tujuan dari perilaku konsumen dan produsen. Setiap kegiatan pembelajaran dilaksanakan dengan menggunakan model pembelajaran cooperative script pada mata pelajaran ekonomi yaitu melaksanakan kegiatan sesuai dengan yang telah di rencanakan di RPP. Selanjutnya untuk melihat perkembangan peserta didik setelah penerapan model pembelajaran cooperative script pada materi yang telah diberikan atau telah dilaksanakan, pada akhir pertemuan peserta didik mengerjakan soal latihan atau (evaluasi), dan pada setiap akhir Siklus I dan Siklus II diadakan ulangan harian yang hasilnya digunakan untuk mengetahui hasil belajar peserta didik dan ketuntasan belajar peserta didik sebagai landasan untuk siklus berikutnya. 
Berdasarkan tes awal diketahui bahwa jumlah peserta didik yang mengikuti tes sebanyak 21 orang siswa yang memiliki nilai tuntas sebanyak 3 orang atau 14,28\% sedangkan yang tidak tuntas sebanyak 18 orang atau dipresentasekan 85,71. Dari tes awal tersebut hanya 3orang siswa yang mencapai standar ketuntasan sedangkan 18 orang belum mencapai ketuntasan dengan rata-rata 51,19. Berdasarkan analisis hasil observasi, hal ini disebabkan pelaksanaan pembelajaran lebih berpusat pada guru, peserta didik pasif atau kurang aktif dan peserta didik kurang konsentrasi terhadap materi yang disajikan oleh guru. Pembelajaran yang berpusat pada guru berlangsung monoton dan membosankan siswa. Pemilihan strategi pembelajaran yang tepat akan memudahkan siswa mencapai tujuan belajar (Widayati, 2004). Pembelajaran yang berpusat pada guru seperti metode ceramah tanpa kombinasi dengan metode yang lain memiliki banyak kekurangan (Hidayati et al., 2013; Maurin \& Muhamadi, 2018), sehingga pembelajaran perlu diubah terutama dengan pembelajaran kooperatif. Menurut Huda (Fredimento \& Sariyyah, 2020), pembelajaran kooperatif merupakan strategi pembelajaran efektif dalam meningkatkan prestasi dan sosialisasi peserta didik sekaligus turut berkontribusi bagi perbaikan sikap dan persepsi mereka tentang begitu pentingnya belajar dan bekerja sama, termasuk pemahaman mereka tentang teman-temannya yang berasal dari latar belakang yang berbeda-beda.

Guna memperbaiki hasil belajar siswa maka perlu dilakukan perbaikan pembelajaran dengan menerapkan pembelajaran cooperative script secara sistematik melalui penelitian tindakan kelas. Pembelajaran cooperative script dipilih sebagai strategi untuk memperbaiki proses pembelajaran disebabkan karena dapat meningkatkan partisipasi belajar siswa (Mustajab et al., 2012) dan juga aktivitas belajar siswa (Hasanah et al., 2020). Berdasarkan hasil penelitian, pembelajaran Cooperative Script juga dapat meningkatkan hasil belajar siswa (Imanuddin, 2020; Mahdalena \& Sain, 2020).

Berdasarkan uraian di atas, maka perancangan perbaikan pembelajaran mengikuti langkah-langkah Cooperatif script. Langkah yang harus dilakukan dalam model pembelajaran Cooperative Script (Meilani \& Sutarni, 2016) sebagai berikut: 1. Guru membagi siswa ke dalam kelompok secara berpasangan; 2. Guru membagi wacana/materi untuk dibaca dan dibuat ringkasannya; 3. Guru dan siswa menetapkan siapa yang pertama berperan sebagai pembicara dan siapa yang berperan sebagai pendengar; 4. Pembicara membacakan ringkasannya selengkap mungkin dengan memasukan ide-ide pokok ke dalam ringkasannya. Selama proses pembacaan, siswa-siswa lain harus menyimak/menunjukkan ide-ide pokok yang kurang lengkap dan membantu mengingat dan menghafal ide-ide pokok dengan menghubungkannya dengan materi sebelumnya atau dengan materi lainnya; 5. Siswa bertukar peran, yang semula sebagai pembicara ditukar menjadi pendengar dan sebaliknya; 6. Guru dan siswa melakukan kembali kegiatan seperti di atas; 7. Guru dan siswa bersama-sama membuat kesimpulan materi pelajaran; dan 8. Penutup.

Penelitian tindakan kelas dilaksanakan dalam 2 siklus, dan setiap siklus terdiri dari 1 kali pertemuan. Adapun langkah-langkah yang dilaksanakan peneliti sebelum memulai pembelajaran pada siklus I antara lain (1) menyusun rencana pembelajaran (RPP) dengan materi perilaku konsumen dan produsen, LKS, soal pre test, soal evaluasi (2) peneliti menyiapkan lembar observasi terhadap aktivitas peserta didik selama proses pebelajaran dan lembar observasi aktivitas guru.

Pada pertemuan pertama, kegiatan awal kurang lebih 10 menit peneliti memberikan salam, berdoa, melakukan apersepsi, memotivasi peserta didik agar memusatkan perhatian pada materi yang akan dijelaskan dan peserta didik juga aktif dalam pembelajaran berupa:(1) Bertanya jawab untuk melihat kemampuan peserta didik; dan (b) mengajak peserta didik memperhatikan dan mendengarkan penjelasan yang diberikan. Peneliti menyampaikan materi dan tujuan pembelajaran yang akan dilaksanakan. Alokasi waktu dalam kegiatan ini 10 menit. Selanjutnya, membagi siswa ke dalam kelompok secara berapasangan; membagi materi untuk dibaca dan dibuat ringkasannya. Setelah membuat ringkasan guru (peneliti) dan siswa secara bersama-sama menetapkan siapa yang pertama berperan sebagai pembicara dan siapa yang berperan sebagai pendengar. Pembicara membacakan ringkasannya selengkap mungkin dengan memasukan ide-ide pokok ke dalam 

Marsel Nande, Yosef Moan Banda, Yofenta Mbaru

DOI: https://doi.org/10.31004/edukatif.v3i2.319

ringkasannya. Kegiatan selanjutnya siswa bertukar peran, yang semula sebagai pembicara ditukar menjadi pendengar dan sebaliknya. Dalam kegiatan penutup peneliti dan peserta didik bersama-sama menyimpulkan materi atau pokok bahasan yang telah mereka diskusikan dalam memberikan tugas kepada peserta didik belajar untuk melakukan evaluasi hari berikutnya.

Dalam penelitian ini menjadi observer adalah guru mata pelajaran ekonomi di SMA Tarvid Ende yang dilakukan observer adalah penelitian memberikan tanda centang pada lebar observasi yang telah disediakan. Hal ini untuk mengumpulkan informasi tentang proses pembelajaran yang dilakukan oleh peneliti di dalam kelas saat pembelajaran sesuai tindakan. Melalui pengumpulan informasi oleh guru mata pelajaran ekonomi maka dapat mengetahui berbagai kelemahan dan kekuatan yang dilakukan dalam melaksanakan tindakan sehingga hasilnya dapat dijadikan masukan ketika peneliti melakukan refleksi untuk penyusunan rencana ulang memasuki putaran atau siklus berikutnya. Berdasarkan hasil obsevasi guru siklus I di atas maka aktivitas guru selama proses berlangsung pada Siklus I dengan nilai rata-rata 73,42 hal ini menunjukan bahwa aktifitas guru berada pada kategori rendah jadi harus ditingkatkan di siklus berikutnya. Selanjutnya, berdasarkan perhitungan hasil tes Siklus I diketahui dari 21 orang peserta didik yang mengukuti tes yang tuntas sebanyak 17 orang atau dipresentasikan 80,95\%, sedangkan yang tidak tuntas 4 orang dipresentasikan $19,04 \%$.

Setelah melaksanakan proses pembelajaran di atas, tindakan selanjutnya diadakan tahap refleksi atas segalah kegiatan yang dilakukan pada siklus I. Berdasarkan kegiatan refleksi siklus I diperoleh fakta bahwa (1) kegiatan guru dalam proses pembelajaran pada siklus I belum berhasil. Masih ada peserta didik yang tidak tuntas pada tes siklus I, peserta didik yang tidak tuntas sebanyak 4 orang maka dilanjutkan pada pembelajaran siklus II; (2) agar peserta didik dapat meningkatkan hasil belajar dan kemampuan dalam pembelajaran ekonomi guru memberikan motivasi, perhatian serta bimbingan dan latihan-latihan kepada peserta didik.

Siklus II dilaksanakan sebagai hasil refleksi pelaksanaan tindakan siklus I. Berdasarkan hasil refleksi maka direncanakan (1) memperbaiki proses pembelajaran karena nilai belum mencapai kriteria keberhasilan yang ditetapkan; (2) membuat skenario pembelajaran untuk mendukung pembelajaran ekonomi; (3) peneliti membuat akan membuat rencana pengajaran dengan membuat RPP dan menyiapkan media pembelajaran; (4)membuat lembar kerja siswa dan peserta didik mengerjakan soal secara individu; dan (5)menyusun lembar evaluasi untuk melihal hasil yang telah dilakukan apakah ada perubahan atau tidak.

Berdasarkan observasi pelaksanaan tindakan siklus II dilakukan oleh guru mengamat diperoleh hasil bahwa aspek-aspek yang diamati pada kegiatan pembelajaran ekonomi sesuai pengalaman peserta didik yang dilaksanakan oleh guru mendapatan penilaian sangat baik. Hal ini dikarenakan guru sudah sangat memotivasi peserta didik dan pengelolaan waktu dalam kegiatan belajar mengajar sudah sangat baik. Dari hasil observasi dilihat bahwa hasil pengamatan aktivitas peserta didik selama mengikuti pembelajaran sangat baik. Proses pembelajarannya telah berhasil dan mencapai nilai yang ditentukan dari sekolah yaitu nilai 65 bahakan mendapat nilai di atas 65 dan telah mencapai nilai ketuntasan minimal (KKM). Hasil tes pada siklus II sesuai pada tabel $10 \mathrm{di}$ atas, terlihat bahwa dari 21 orang peserta didik yang mengikuti tes, semuanya tuntas atau dipresentasikan $100 \%$. Berdasarkan proses pelaksanaan penelitian tindakan kelas dinyatakan berhasil dalam 2 siklus dan pembelajaran cooperative script dapat meningkatkan hasil belajar ekonomi para peserta didik kelas X SMA Tarvid Ende. Ringkasan hasil tindakan sejak pra penelitian, tindakan siklus I dan tindakan siklus II disajikan pada Tabel 1. 
Penerapan Hasil Belajar Mata Pelajaran Ekonomi dengan Model Pembelajaran Coorperative ScriptMarsel Nande, Yosef Moan Banda, Yofenta Mbaru

DOI: https://doi.org/10.31004/edukatif.v3i2.319

Tabel 1

Daftar Ketuntasan Belajar Peserta Didik pada Tes Awal Hasil Tes Siklus I dan Hasil Tes Siklus II

\begin{tabular}{|l|c|c|c|}
\hline \multirow{2}{*}{ Nama siklus } & \multicolumn{2}{|c|}{ Skor } & \multirow{2}{*}{ Persentase } \\
\cline { 2 - 3 } & Kurang dari 65 & Lebih dari 65 & \\
\hline Pre Test & 18 orang & 3 orang & $14,28 \%$ \\
\hline Siklus I & 4 orang & 17 orang & $80,95 \%$ \\
\hline Siklus II & 0 & 21 orang & $100 \%$ \\
\hline
\end{tabular}

Berdasarkan Tabel 1 hasil tes siklus I dan siklus II di atas terjadi peningkatan pertisipasi peserta didik dalam mengikuti kegiatan belajar mengajar sehingga peserta didik dapat mencapai kriteria ketuntasan minimal (KKM). Hal ini dipengaruhi oleh peningkatan partisipasi siswa dalam pembelajaran yaitu dari partisipasi cenderung negatif menjadi positif. Hal ini hampir sama dengan penelitian yang dilakukan oleh Mustajab et al., (2012), dimana dalam penelitiannya dapat dibuktikan peningkatan partisipasi siswa dalam belajar ketika pembelajaran mengggunakan model cooperative script. Pembelajaran cooperative script berdasarkan hasil penelitian ini berhasil meningkatkan aktivitas belajar siswa. Hasil ini sesuai dengan prediksi yang berdasarkan hasil penelitian terdahulu membuktikan bahwa pembelajaran cooperative script efektif untuk meningkatkan aktivitas belajar siswa (Hajaryanti \& Kuraedah, 2018; Hasanah et al., 2020).

Peningkatkan partisipasi dan aktivitas belajar siswa dalam pembelajaran cooperative script berkontribusi pada peningkatan hasil belajar ekonomi peserta didik kelas X SMA Taruna Vidya Ende. Peningkatan hasil belajar para peserta didik yang terbukti dalam penelitian tindakan kelas ini juga sama dengan penelitian lain yang telah dilakukan oleh para peneliti terdahulu seperti Imanuddin (2020) serta Mahdalena \& Sain (2020). Berdasarkan hasil penelitian yang telah dijustifikasi dengan berbagai penelitian dan teori di atas, hasil penelitian ini dapat berkontribusi bagi para guru guna proses perbaikan pembelajaran mata pelajaran ekonomi jika mengalami masalah pembelajaran serupa. Keterbatasan penelitian ini adalah bahwa penelitian ini hanya berupaya meningkatkan hasil belajar siswa dalam ranah kognisi sesuai masalah yang diidentifikasi pada subyek di lokus penelitian ini.

\section{SIMPULAN DAN SARAN}

Berdasarkan pembahasan di atas dan sesuai dengan tujuan dari penelitian ini maka dapat disimpulkan bahwa penerapan model pembelajaran cooperative script pada peserta didik kelas X di SMAK Tarvid Ende dengan materi ajar perilaku konsumen dan produsen telah dilaksanakan melalui penelitian tindakan kelas dengan 2 siklus dan penelitian ini dikatakan telah berhasil dengan baik. Hal ini ditunjukkan dengan peningkatan hasil belajar peserta didik dimana pada Siklus I dengan nilai rata-rata kelas adalah 77,14dengan taraf ketuntasan 80,95\%. sesuai dengan KKM yang ditentukan dari pihak sekolah adalah 65, maka di siklus I ini dikatakan belum berhasil; sedangkan pada siklus II dengan nilai rata-rata kelas adalah 79,04 dengan taraf ketuntasan $100 \%$. Nilai rata-rata kelas yang diperoleh pada siklus II ini telah mencapai standar KKM yang ditentukan. Dengan demikian hasil penelitian ini dapat dijadikan contoh penyelesaian masalah pembelajaran bagi guru, sekolah dan mata pelajaran lain di SMA maupun tingkat sekolah lainnya jika mengalami masalah yang sama. 

Marsel Nande, Yosef Moan Banda, Yofenta Mbaru

DOI: https://doi.org/10.31004/edukatif.v3i2.319

\section{DAFTAR PUSTAKA}

Alangui, W. V. (2010). Stone walls and water flows: Interrogating cultural practice and mathematics. researchgate.net.

https://www.researchgate.net/profile/Willy_Alangui/publication/44926341_Stone_walls_and_water_flo ws_Interrogating_Cultural_Practice_and_Mathematics/links/57273d9208aef9c00b8b1dcd/Stone-wallsand-water-flows-Interrogating-Cultural-Practice-and-Mathematics.

Alie, N. H. (2013). Penggunaan model pembelajaran kooperatif tipe nht untuk meningkatkan hasil belajar siswa kelas x2 sma neg. 3 gorontalo pada materi jarak pada bangun ruang. Jurnal Entropi, $8(01)$.

Darkasyi, M., Johar, R., \& Ahmad, A. (2014). Peningkatan kemampuan komunikasi matematis dan motivasi siswa dengan pembelajaran pendekatan quantum learning pada siswa SMP Negeri 5 Lhokseumawe. Jurnal Didaktik Matematika, 1(1).

Darojat, Q., Ani, H. M., \& Suyadi, B. (2018). Penerapan Model Pembelajaran Cooperative Script Untuk Meningkatkan Keaktifan Dan Hasil Belajar Siswa. JURNAL PENDIDIKAN EKONOMI: Jurnal Ilmiah Ilmu Pendidikan, Ilmu Ekonomi Dan Ilmu Sosial, 12(2), 207-213.

Ekawati, F. (2018). MANAJEMEN SUMBER DAYA MANUSIA DALAM MENINGKATKAN MUTU PENDIDIKAN DI SMPIT. Jurnal ISEMA: Islamic Educational Management, 3(2), 118-139.

Fakhruddin, A. (2011). Prinsip-Prinsip Manajemen Pendidikan Islam dalam Konteks Persekolahan. Jurnal Pendidikan Agama Islam-Ta'lim, 9(2), 199-212.

Fredimento, A., \& Sariyyah, N. (2020). Model Pembelajaran Kooperatif Tipe Numbered Head Together dalam Pembelajaran IPA di SDK St. Maria Imaculata Ende 8 Kabupaten Ende. Prima Magistra: Jurnal Ilmiah Kependidikan, 1(1), 38-46.

Hajaryanti, H., \& Kuraedah, S. (2018). Meningkatkan Aktivitas Dan Hasil Belajar Pendidikan Agamai Islam Melalui Model Pembelajaran Cooperative Script. Al-TA'DIB: Jurnal Kajian Ilmu Kependidikan, 11(1), 154-170.

Hasanah, U., Damayani, A. T., \& ... (2020). KEEFEKTIFAN MODEL DISCOVERY LEARNING BERBASIS ETHNOMATHEMATICS MATERI BANGUN DATAR TERHADAP HASIL BELAJAR PESERTA DIDIK .... Elementary School: Jurnal .... https://journal.upy.ac.id/index.php/es/article/view/1074

Hidayati, A., Salawati, T., \& Istiana, S. (2013). Pengaruh pendidikan kesehatan melalui metode ceramah dan demonstrasi dalam meningkatkan pengetahuan tentang kanker payudara dan ketrampilan praktik sadari (Studi pada Siswi SMA Futuhiyyah Mranggen Kabupaten Demak). Jurnal Kebidanan, 1(1), 1-8.

Imanuddin, N. (2020). Model Pembelajaran Cooperative Script Sebagai Upaya Meningkatkan Hasil Belajar Geografi Materi Bumi Sebagai Ruang Kehidupan. Attractive: Innovative Education Journal, 1(2), 2642 .

Jailani, M., \& Qudsiyah, U. (2020). Integrasi Problem Based Learning Dengan Model Cooperative Script Untuk Meningkatkan Hasil Belajar Ekonomi Pada Siswa Di SMA Muhammadiyah 1 Palangkaraya. Soedirman Economics Education Journal, 2(1), 55-71.

Kusmayadi, G. (2017). Pengaruh Kebijakan Pembiayaan Pendidikan Dan Kompetrensi Guru Penjas Terhadap Prestasi Olahraga (Studi Pada Sekolah Dasar Negeri Wilayah Manonjaya Kabupaten Tasikmalaya). Administrasi Pendidikan: Jurnal Ilmiah Mahasiswa Pascasarjana, 1(1), 17-22.

Lambiotte, J. G., Dansereau, D. F., O’Donnell, A. M., Young, M. D., Skaggs, L. P., \& Hall, R. H. (1988). Effects of cooperative script manipulations on initial learning and transfer. Cognition and Instruction, 5(2), 103-121.

Lumbanbatu, R. (2020). PENERAPAN MODEL PEMBELAJARAN COOPERATIVE SCRIPT DALAM MENINGKATKAN HASIL BELAJAR SISWA PADA MATA PELAJARAN EKONOMI KELAS X DI SMA NEGERI 1OMEDAN TAHUN AJARAN 2019/2020. 
403 Penerapan Hasil Belajar Mata Pelajaran Ekonomi dengan Model Pembelajaran Coorperative ScriptMarsel Nande, Yosef Moan Banda, Yofenta Mbaru

DOI: https://doi.org/10.31004/edukatif.v3i2.319

Mahdalena, S., \& Sain, M. (2020). Meningkatkan Hasil Belajar Siswa Melalui Penerapan Model Pembelajaran Cooperative Script Pada Mata Pelajaran Ilmu Pengetahuan Sosial Kelas VA Siswa Sekolah Dasar Negeri 010 Sungai Beringin. Asatiza: Jurnal Pendidikan, 1(1), 118-138.

Maurin, H., \& Muhamadi, S. I. (2018). Metode Ceramah Plus Diskusi dan Tugas Untuk Meningkatkan Aktivitas Belajar Siswa. Al-Aulad: Journal of Islamic Primary Education, 1(2).

Meilani, R., \& Sutarni, N. (2016). Penerapan model pembelajaran cooperative script untuk meningkatkan hasil belajar. Jurnal Pendidikan Manajemen Perkantoran (JPManper), 1(1), 176-187.

Mustajab, M., Sriyono, S., \& Fatmaryanti, S. D. (2012). Penerapan Metode Pembelajaran Cooperative Script Untuk Meningkatkan Partisipasi Belajar Siswa Kelas VIII A Smp Negeri 2 Karanggayam Tahun Pelajaran 2012/2013. Radiasi: Jurnal Berkala Pendidikan Fisika, 1(1), 37-40.

Ningrum, E. (2016). Pengembangan sumber daya manusia bidang pendidikan. Jurnal Geografi Gea, 9(1).

Rahayaan, I., Azwan, A., \& Bugis, R. (2016). The Students' Writing Ability through Cooperative Script Method. Jurnal Retemena, 2(2).

Rosdi, I. (2020). Meningkatkan Minat dan Hasil Belajar Siswa Pada Mata Pelajaran Ekonomi Melalui Pembelajaran Kooperatif Tipe TPS (Think Pair Share). Indonesian Journal of Social Science Education (IJSSE), 2(2), 191-198.

Supiana, S., Hermawan, A. H., \& Hilmy, M. F. (2018). MANAJEMEN SARANA DAN PRASARANA DINIYAH TAKMILIYAH. Jurnal Isema: Islamic Educational Management, 3(2), 140-158.

Sutardi, S., \& Sugiharsono, S. (2016). Pengaruh kompetensi guru, motivasi belajar, dan lingkungan keluarga terhadap hasil belajar mata pelajaran ekonomi. Harmoni Sosial: Jurnal Pendidikan IPS, 3(2), 188-198.

Widayati, A. (2004). Metode mengajar sebagai strategi dalam mencapai tujuan belajar mengajar. Jurnal Pendidikan Akuntansi Indonesia, 3(1). 